In this issue:

Annual Report of the President 1976-77

Yale Center for British Art Opened

Letters

ACRL Chapters

News from the Field

People

Publications

Classified Advertising

\section{COLLEGE \\ \& RESEARCH \\ LIBRARIES \\ MCIDS}

NO. 7 • JULY/AUGUST

\title{
Association of College and Research Libraries: Annual Report of the President 1976-77
}

This past year has been one of substantial change and significant accomplishment for the Association of College and Research Libraries. Major changes include the resignation of the executive secretary and the appointment of her replacement, the resignation of the editor of Choice, and the establishment of a new section. Among many important accomplishments were the publication of several guidelines statements and the addition of two new chapters.

In January, Executive Secretary Beverly P. Lynch left ACRL to become university librarian at the University of Illinois at Chicago Circle. Under her dynamic leadership, ACRL was able to expand and improve its programs in spite of increasingly severe budgetary constraints. The association will be forever indebted to her. A search committee was appointed to assume the difficult task of finding a successor who could maintain the high standards ACRL members have come to expect. At the Midwinter Meeting, Julie A. Virgo, director of education at the Medical Library Association, received the unanimous and enthusiastic endorsement of the search committee. She assumed her new position as ACRL executive secretary on April 4.

At midyear, Richard K. Gardner announced his resignation as editor of Choice, effective June 1 , to accept a full professorship at the Graduate School of Library and Information Science at UCLA. In January, a committee chaired by Beverly Lynch was appointed to search for a successor. Dr. Gardner served as editor of Choice for two separate terms totaling eight years. During his tenure he developed Choice into a very important review journal, highly respected and valued not only by academic librarians but also by those in all other areas of librarianship. His contribution to the profession through Choice is outstanding.

At the recommendation of the ACRL Bibliographic Instruction Task Force and in response to mounting membership interest, the ACRL Bibliographic Instruction Section was established at Midwinter. In order to make preliminary plans and to develop a temporary organizational structure without delay, a steering committee-headed by Mimi Dudley, associate librarian, College Library, UCLA-was appointed immediately after Midwinter. The committee was charged with determining the organizational structure of the section, appointing a nominating committee to nominate candidates for the 1978 elections, establishing provisional committees, and providing for the smooth operation of the section during its first year of existence. The section will replace the Bibliographic Instruction Task Force and will be responsible for, among other things, the development of policy statements on bibliographic instruction, the sponsorship of programs at conferences, and cooperation with other groups in areas of mutual interest.

ACRL publications continue to be among the division's most important and appreciated programs. Under the expert guidance of Editor Richard D. Johnson, College \&. Research Libraries has continued to make a significant con- 
tribution to academic librarianship. For ALA's centennial celebration, the 1976 issues of C $U R L$ included a series of articles which treated all major developments of college and university libraries during the 100 years since ALA's founding. The articles are being collected and published as a monograph in the ACRL Publications in Librarianship series. With the January 1977 issue of College \& Research Libraries News, John V. Crowley, assistant director of libraries, State University College, Oneonta, New York, became editor, succeeding Mary Frances Collins, assistant director of libraries for technical services, State University of New York at Albany.

During the past year, the association approved several policy statements and guidelines: "Guidelines for Bibliographic Instruction in Academic Libraries" (C\&RL News, April 1977); "Statement on Access to Original Research Materials in Libraries, Archives, and Manuscript Repositories" (CURL News, November 1976); "Statement on the Reproduction of Manuscripts and Archives for Noncommercial Purposes" (C dRL News, November 1976); and "Statement on the Reproduction of Manuscripts and Archives for Commercial Purposes" (C\&RL News, May 1977). Draft guidelines and procedures for the screening and appointment of academic librarians have been developed and published; and committees are working on the development of standards for university libraries and quantitative standards to accompany the "Guidelines for Two-Year College Learning Resources Programs."

ACRL this past year completed a major survey of the salaries of academic librarians. The results of the survey, which was funded by the Council on Library Resources and conducted for ACRL by Richard Talbot and Ann von der Lippe, were published in August 1976 as Salary Structures of Librarians in Higher Education for the Academic Year 1975-76.

When ACRL expressed its desire to assume full responsibility for Choice, ALA Executive Director Robert Wedgeworth appointed an ad hoc committee to study the question. The study team, chaired by Thomas J. Galvin, dean, Graduate School of Library and Information Science, University of Pittsburgh, presented a masterfully written report recommending that ACRL be assigned managerial, fiscal, and editorial responsibility for Choice. The report, which stipulates that an adequate reserve fund be created to accommodate fluctuations in income and expenses and that deficit financing be avoided, provides a general policy framework for the administrative and fiscal management of the magazine.

At the 1977 Midwinter Meeting, two new ACRL chapters were given official recognition by the Board of Directors: the Academic and
Research Libraries Division of the Maryland Library Association and the Southern California Association of College and Research Libraries.

To celebrate its fortieth anniversary, ACRL will join with its New England chapter to host a national professional conference in Boston in November 1978. The conference will give academic librarians an opportunity to discuss issues and problems without the distraction of business and committee meetings. The conference theme is "New Horizons for Academic Libraries." George R. Parks, dean of university libraries, University of Rhode Island is serving as conference chairperson.

Two major programs were planned as part of the 1977 ALA Annual Conference in Detroit. The division's general program featured a major address by Stephen K. Bailey, acting president of the American Council on Education, entitled "The Future of College and Research Libraries: A Washington Perspective." His talk emphasized economic trends and their impact on libraries. The ACRL Rare Books and Manuscripts preconference was held in Toronto, June 14-17. The preconference theme was "Book Selling and Book Buying: Aspects of the Nineteenth-Century British and North American Book Trades." Special exhibitions to complement the preconference theme were presented in a number of local libraries. Numerous ACRL section and discussion-group programs also were planned for the Detroit Conference.

News ifems lor inclusion in C\&RL News should be sent to John $V$. Crowley. Assistant Director of Libraries, Milne Library, State University College, Oneonta, NY 13820. Advertising (including classified ads) should be sent to Leona Swiech, Advertising Oflice, American Library Association, 50 E. Huron St., Chicago, IL 60611 . Production and circulation matters are handled by ALA Central Production Unit, at the above address.

News editor: John V. Crowley, Assistant Director of Libraries, Milne Library, State University College, Oneonta, NY 13820. Associate news editor, William B. Weiss, Assistant Librarian Cataloging Department, Milne Library State University College, Oneonta, NY 13820. Editor: Richard D. Johnson, Milne Library, Stafe University College, Oneonta, NY 13820.' President, ACRL: Connie R. Dunlap. Executive Secrefary, ACRL; Julie A. Virgo.

College \& Research Libraries is published by the Association of College and Research Libraries, a division of the American Library Association 17 times yearly- 6 bimonthly journal issues and II monthly (combining July-August) Nows issues-at 1201-05 Bluff St. Fulton. MO 65251. Subscription. $\$ 15.00$ a year or to members of the division. \$7.50, included in dues. Second-class postage paid at Fulton, Missouri 65251 .

(1) American Library Association 1977. All material in this journal subject to copyright by the American Library Association may be photocopied for the noncommercial purpose of scientific or educafional advancement. 
The ACRL Subcommittee on Goals, Priorities, and Structures, chaired by Le Moyne W. Anderson, director of libraries, Colorado State University, is completing a monumental three-year study which has attempted to develop an organizational structure for ACRL that can respond both to the welfare of the profession and to the issues of library services in the changing environment of academic libraries. The subcommittee's semifinal draft report proposes a radical restructuring of the association, better to meet changing needs. During the coming year, the report will be given careful study. Implementation of any or all of the report's recommendations will be subject to ACRL Board approval.

In an attempt to increase membership in the association, the chairperson of ACRL's Membership Committee, Thomas H. Cahalan, assistant librarian for acquisitions, Northeastern University, has developed a promotional network comprising regional and state representatives throughout the United States and Canada. It is hoped that working through regional groups and chapters will stimulate increased in- terest in ACRL and its programs. Special brochures have been developed for use in state and regional meetings, and their effectiveness will be evaluated to determine the best ways to reach potential members.

The specialized interests of ACRL's committees and sections are so diverse and wide-ranging that space does not permit adequate reporting of all of them. All have served their constituencies well and have continued to make important contributions to their areas of special interest as well as to the association. The success of ACRL's programs and their impact on the profession are directly attributable to the combined energy, talent, and dedication of ACRL officers and committee members.

The association mourned the tragic loss of its immediate past president, Louise Giles. She had been an unusually active and productive participant in ACRL and ALA affairs, and her absence will be keenly felt for many years.

Connie R. Dunlap

President, ACRL

\section{Yale Center for British Art Opened}

A new museum and study center-the Yale Center for British Art-was officially opened to the public April 19 in New Haven.

The gift of Paul Mellon (Yale class of 1929), the center will house Mellon's unrivaled collection of British paintings, drawings, prints, and rare books. The center will offer reference material for advanced research in the field of British art; classrooms; and other facilities for a broad program of activities in British studies.
The addition of the Mellon collection to the university's already extensive holdings of English books and autograph letters makes Yale a leading institution for the study of British art and culture outside of England.

The center is the final building designed by the late Louis I. Kahn (1901-74), internationally distinguished architect, who also designed the Yale University Art Gallery (1951-53) and the Kimbell Museum in Fort Worth, Texas
The reference library is located on the second floor, with a photographic archive and storage stacks housed on the mezzanine above.

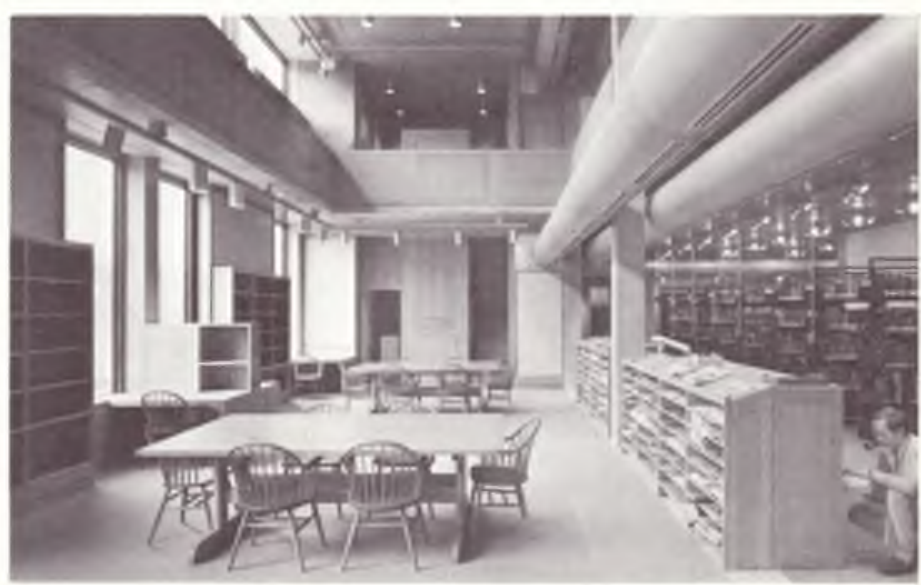

